\title{
Looking in the Rear-view Mirror: Reverse Chronicle of Covid-19 Lockdown in Serbia
}

Jun 25 2020. As I am writing these lines, the number of infected from COVID-19 rose once more, heading, as one medical official said, towards its second peak in the (still) first wave of the epidemic. We are approaching the same old confusing discourse we have already went through, in which numbers indicating the tested, the infected, self-isolated, hospitalized, recovered and deceased will linger around while we are "dancing with the virus" again. The latest information, revealed by an independent news portal, claims that the authorities have been hiding the real number of the infected and deceased from the beginning and that those numbers are two to three times higher than officially reported. Suspicion is growing - there is an overwhelming distrust in every institution and every official body in charge of handling of the epidemic. The absurdity and sheer cruelty of political games around the epidemic leave me speechless. At the moment, I am perplexed, and the best I can do is to share some of the observations, thoughts and reflections made throughout the lockdown (which in Serbia was unusually strict, with policing hours and curfews that at some points lasted for 2-3 days). My notes are organized as a reverse chronicle of events during the Serbian lockdown - a perspective which resembles looking at the rearview mirror. I have mostly extracted them from Facebook posts and comments, another testimony of an unusual times and challenges we are to face in the months or years to come, grappling with the evergrowing digitalization of every aspect of our lives. They will obviously lacking consistence and nuance I would otherwise be aspiring to; still I believe that they could convey the sense of mental paralyses and the slowness we face in encounter with an unknown threat, or unbelievable inhumanity, in spite of the intellectual challenge it simultaneously poses. 
May 4. What should the citizens do when those elected to protect their rights and liberties are in fact active accomplices, even organizers, of unlawful activities, aimed to frighten and discourage the same citizens they are to represent? This is the fourth or fifth evening in the row that unknown men broke into highrise buildings or buildings under construction, to set off football-hooligan-style fireworks and play the pre-recorded audio sample of derogatory messages relating to the political opposition from loudspeakers. The soundscape is frightening, as is the iconography (all robust men dressed in black), and the fact that all of this is happening during the curfew and that police, if they came at all, actually helped those men to leave the spot, is even more worrisome. The State publicly denies any connection to these events, but by turning a blind eye it is, in fact, encouraging them. They use the "men in black" as a proxy to intimidate all those people who have been protesting for days the State's handling of the epidemic by making "noise" from their windows and balconies - banging pots and pans, playing music, and whistling as they used to do back in the nineties. Nevertheless, even though creative answers are welcome and do bring a sense of gratification for those engaged in it, I feel that we have to devise other ways of non-violent resistance and subversion in order to fight for our individual rights and freedoms, but also to maintain the endangered rule of law. What we need are protocols and codes for civil action, and our answers to any violation of the code of law have to be massive and uniform in order to be seen, heard and taken into account. We'll have to remain persistent in small everyday activities aimed to keep our focus on basic, inalienable values of communal life in democratic societies, and have to resist as many distractions as possible on a way along.

May 3. I am afraid that this evening the roof of our building could be (mis)used for football-hooligan-style fireworks. Feeling that something has to be done, and that legal mechanisms are to be used in order to be maintained (even if we distrusted their efficiency so far), I engage in micro-campaigning. Emails and text messages were sent to the building manager alerting her to the possible developments, and an appeal on Facebook asking for advice posted. Finally, I draw a visually naive, but obviously vernacular, poster banning "unlicensed person entry to our building and roof terrace" and put it on a building entrance. At the end of the day, they kept off our building, but found another "host" for the evening, just behind us.

April 23. Still observing the situation with spreading the Corona virus among church dignitaries, after holding the Easter Liturgy. We have been informed that the closest associate of the Patriarch Irinej was infected, but not much else was reported.

April 21. Almost a week long tedious conversation between the Serbian Orthodox Church and the State is finally brought to the end. Easter has passed, and it seems that some of kind of compromise has been achieved between forcing the public health measures and the conservative attitude of the Church whose 
prominent dignitaries publicly proclaimed that "churches are sacred places which had been safe for centuries"; and also that "God was watching over the believers". The compromise was that the Patriarch agreed to serve the Liturgy in the empty church. Still, the belief that the virus is powerless in sacrosanct time and place was shared by many people who eventually turned up at the Easter Liturgy, though the churches were emptier than they usually are at holydays. We are indeed used to this kind of the Church and the State flexing their muscles, but this time it brought about an unprecedented irritation of the public, raising questions about moral integrity of the Church and its clergy, and the capacity and preparedness of the State to act in the public interest.

April 18. Reading Danny Roderick's text about how virus is going to change the world and transform politics and economy on global and national levels. Mostly agree with what is said - although a lot of the written is indeed a résumé of the already evident developments, we have to begin with something in trying to understand what is happening and where it leads to. The one thing I disagree with is the measure of importance attributed to the main actors, and distributed among them: it seems to me that the most powerful "player" will be the Corona virus itself, and that all responses - be they institutional, social or individual, on an international, national or local level - will be conditioned by its still uncertain, unpredictable and uncontrollable path. Economy, politics and the rest of social life will have to find ways to adapt to this uncertainty writ global. A piece of trivia (or not so): Washington Post published a story about a casino owner in Las Vegas, who had to call a locksmith and have a new lock installed in order to close the building, because the doors on his 24-hour casino hadn't been locked since he opened the place 18 years ago, and he lost the key.

April 15. Thinking out loud: is it possible that the Orthodox believers will be more responsible toward themselves and the others around them than the Patriarch and church dignitaries seem to be, by openly inviting people to disobey public health measures to "be responsible and stay at home", and attend the Easter Liturgy instead. Varying answers and comments on my Facebook post showed wide spectrum of attitudes - some of them steaming from widespread autoorientalization (pessimistic view), some giving credit to an allegedly superior sobriety and rationality of common folk (optimistic view). Cannot wait to see the outcome.

April 12. And here it goes: this is the point where epidemic, whose management is beyond doubt a political issue from the very beginning and throughout, turned servant to a banal political partisan propaganda. Before the official announcement of the daily number of infected was made, the President of Serbia alarmed the public about the "newest trouble spot" in a town in Southern part of Serbia. Soon after we learned from the doctors that the same number of infected were found in other places, it became clear that the „(political) gloves are off” and that the epidemic will be used for a shameless partisan campaign. In truth, Presi- 
dent, who is a self declared PO addict, eventually occupied the entire political and social space and has completely taken over the performance of many - formally and factually - distinctive roles. This came to be even more outstanding during the epidemic when he acted as a political leader, economic juggler (trying to secure ventilators on an unregulated and shady market), caring father of the nation (and a devoted son of the elderly citizens whom he declared "the most valuable, still fragile part of the nation"), distributor of medical supplies who handed them down personally to every spot in Serbia. Actually, he showed up in the abovementioned town to deliver ventilators in person. This kind of almightiness is reminiscent of the mythic figure of medieval St. Sava, on which the canon of the omnipotent ruler was established in 19th c. nation-building discourse (according to Serbian tradition, St. Sava had, aside from his role as spiritual and educational leader, also taught the Serbs how to plow, weave, sew, and produce honey). From now on, medical and political aspect of the epidemics are clearly parted and will go in separate ways.

April 8. As the days and weeks pass, we get to learn more about adaptability and resilience as important parts of human condition. So far we have already established new routines regarding provision under lockdown, and are coping to overcome anxieties provoked by the rise of hygienic standards, at home and outside. At moments it is like we are living a nightmare - it seems that our reasoning, regardless if we are believers or not, has been affected by some kind of neo-magical urge: we clean the home relentlessly, don't go outside if not armed by disinfects and "protected" with masks and gloves, construct an elaborated ritual over crossing the boundaries of home - cleaning ourselves and whatever we brought home with a belief that if only we properly disinfect it we'll be able to protect ourselves, and more importantly to regain the sense of security. When I managed to relax a bit in relation to manic cleansing, I started to observe more attentively what was happening on the street, and eventually developed it into a daily ritual. I used to lean from the window after the curfew started, watching people in the streets hurrying home, relaxing or doing chores in the yards across the street. More than ever before I engaged in a casual people-watching as wide and faraway as my fifth floor window perspective could allow. The picture of myself as leaning through the window resembled old ladies in small towns who used to monitor the happenings in their locale, and I found that amusing. Nonetheless, during these episodes I could also sense the amazing "sound of silence" that dominated my experience of the lockdown, but was not solely mine either, nor was restricted only to Serbia. Thus, I remember that one Sunday morning I could hear from my terrace on the fifth floor the heavy breathing of a dog taken to a stroll across the street, while a friend living in Italy was amazed that he could hear how the date pit he throw over the balcony hit the asphalt in front of his three- storey building.

March 30. Useful advice from our parents' and grandparents' era: Wipe the shoes at the door mat before entering the apartment! Take off the shoes in the 
hallway! Wash your hands with soap and water! Change your clothes! Don't pick your nose! Don't bite your nails! Wash your hands regularly with soap and water - before and after meals! Do not drink from others' glasses! Cut your nails regularly and wash them thoroughly with the brush. Wash the hands. Wash the hands. Wash the hands. Vintage or evergreen? Public health measures or a tight upbringing many of us still remember?

March 28. Anthropological wisdom concerning epidemics says that while viruses (and infectious diseases which some of them provoke) are always new, human responses to it are not. What we can hear from the top-ranked politicians these days has already been described and analyzed as "othering" - a mechanism of producing and putting social stigma on certain social groups or parts of population. It could be done either through development of discourse of "dangerous bodies" seen in popular medical discourse as a "mobile container of contagion" (those already ill or seen as a potential threat: migrants, refugees, tourists, domestic migrant workers etc.), or their immobilization and isolation in various places that are part of provisional anti-Covid infrastructures. Narratives constituting so called geographies of blame, that is pinpointing those who are to be "guilty" for bursting out of epidemic and/or spreading the disease, are widely circulating. In Serbia, 400.000 migrant workers are attempting to come back from (mostly) Western European countries, and the ruling party openly blamed them for purposefully spreading the decease, thus transforming the act of coming home into an act of national treason.

March 17. After trying for rather a long time to figure out what or who could act as a decisive force in stopping, or overturning the course of global events (it seemed as unstoppable and fully suicidal), the answer came from where it was not expected. While subjects in dramatic events that unfold before our eyes globally and locally are still humans who suffer and cope with the unknown disease, it seems that the main role in the reconfiguration of the world after the epidemic will be played by a non-human actor - intelligent, adaptable, transformable, mobile form of life which uses people as habitat and resource for reproduction. What a lecture this is to our deeply internalized anthropocentrism! And not less a challenge for future anthropological research.

March 15. State of emergency declared. Borders are closed, movement restricted (the most severe for those 65 years +, who are banned from leaving their homes) and curfews installed. Every day "from dusk to dawn" the entire population is locked down.

March 12. My biggest fear at the moment is not the disease, but the realization that our incompetent politicians will be in charge with the management of the epidemic. That is really frightening! When I heard them cracking jokes about rakija as a cure for Corona, or making inappropriate comments that the virus is "irrelevant", that people should go to Italy for shopping (at the moment when Italy was facing a major health and social crisis), a decision was born from despair: 
not listening to them but following advice of my close friends living in Italy and exchanging views and experiences with people whose sanity remained intact. The plan for the following period is to do whatever is needed to avoid becoming the "object" of their care and management.

March 8. I noticed that people are sharing more information (or "information") related to the epidemic. It is as if an ,infodemic" is also spreading through the society, bringing in competing discourses on the epidemic, its biosocial power and its medical, economic, political, social backgrounds and effects. You can feel that the disease came closer, that the danger is real, and people are starting to pay attention to advice on how to behave and what precautionary measures each of us should take. My attention was drawn to a text written by Italian doctor, who underlined the political lessons we as humanity should learn from the outbreak of Covid-19 pandemic and from the way global community mobilized around it. She wrote that it was evident that global society was able to mobilize, to launch the activity of global institutions as WHO, to create a global answer and design global measures and recommendations for fighting the pandemic. When we see that swift, concerted activities are possible if we share the feeling of urgency and of common threat, then the next logical question would be why it was not possible before, and why global society seem so incapable to find intelligent, fair, equitable, just solutions and develop a course of action when issues as wars, famine, extreme social inequality, or unhealthy living conditions for great portion of world populations are still on the agenda.

March 6. Still processing the impact of remarkable Conference on Woman in Academia held in SASA in Belgrade last month. So many great scholars, thinkers, activists, friends gathered at one place, and so many imagination and plans were set for future activities! I also remark that today the first case of Corona infection is officially registered in Serbia. 